In the acute stage, and particularly if there is much swelling and pain, a wick of wool or gauze may be left in the ear for 24 hours, and a solution of one part metacresyl acetate ("cresatin") to three parts of the oily mercurial drops mentioned above may be used to soak the wick in and also to drop into the ear on top of the wick every four hours. A $3 \%$ solution of aluminium acetate instead of the oily drops often helps to reduce the swelling. The infecting organism will often be found to be Gram-negative, and as a rule the most effective antibiotic is choramphenico by mouth. The local application of chloramphenicol or polymyxin is successful in some cases, but as it is sometimes irritating it is probably better to avoid such application in acute cases.

Recurrent otitis externa may sometimes be associated with dandruff, and in such cases a scalp lotion containing mercury and salicylic acid and sulphur will be helpful. Patients with obstinate external otitis should be advised to avoid at all costs getting water into their ears. Although otitis externa may not be accompanied by any obvious discharge, it will often be found that there is debris in the ear canal, particularly in its deeper and more inaccessible part, and until this debris has been thoroughly cleared out the inflammation is unlikely to subside.

\section{Potatoes and Sulphur Dioxide}

Q.-Some cooks soak peeled potatoes overnight in water to every gallon (4.5 litres) of which they add 1 tablespoonful (14 ml.) of a preparation containing approximately $9 \%$ of sulphur dioxide. What is the object in doing this, and is the practice harmful?

A.-Preparations containing sulphur dioxide, in chemically combined form, act as strong reducing agents. They have proved very effective for preserving fruits and vegetables both in domestic bottling and in manufacturing processes. Presumably they are added to the water covering peeled potatoes in order to prevent blackening, which otherwise may tend to occur through the oxidation of tyrosine to melanin by an enzyme liberated from the damaged tissues. The sulphur dioxide also protects vitamin $C$. There is no evidence that it is harmful in the amounts which are used.

\section{Low-protein Diets and High Fertility}

Q.-I understand that J. R. Slonaker showed that rats fed on diets containing very little protein had particularly large and numerous litters. Has this work been confirmed? Is there any reason to believe that a similar effect may occur in man?

A.- In speaking of "particularly large and numerous litters" the questioner is under a misapprehension about normal reproduction in the rat. The laboratory rat has an average litter size of 7 to 8 young, and very large litters of 15 or 16 young are not uncommon in most strains, the largest litter size at birth recorded for the Wistar colony of albino rats being 18 . In the experiments recorded by Slonaker on the effect of different proportions of protein in the diet of rats, the largest average litter size reported was 5.7 young. This is clearly well below the average for a normal healthy stock receiving an adequate diet. The diet contained $14 \%$ protein.

In the preparation of the diets having different protein contents the increased protein was obtained in Slonaker's experiments by the addition of increasing amounts of meat scrap to a basal mixture of constant formula, thus progressively diluting it. At the highest level (26\% protein) about $50 \mathrm{~g}$. meat scrap was added to every $100 \mathrm{~g}$. basal mixture. Even a " rich" diet would be unlikely to withstand such dilution without the risk of becoming deficient in some essential factor not present in meat scrap. Moreover, the basal diet used by Slonaker was not adequate. Apart from the poor reproduction at all protein levels the females lost weight during lactation, which does not occur if the diet is adequate.
The small litter size obtained with the higher levels of protein in Slonaker's diets is likely to be the result of a deficiency in the diet and not of the level of protein. The work has not been confirmed. On the contrary, better reproduction in rats on a diet containing $40 \%$ protein than on diets containing $25 \%$ or $15 \%$ protein has been reported by McCoy (J. Biol. Chem., 1940, 133, 1xiv). In this work the concentration of vitamins, minerals, and fats was kept constant, and the added protein replaced dextrin in the diet.

It is well known that fertility in man is not dependent on a high nutritional level.

\section{Recurrent Urinary Symptoms after Coitus}

Q.-What are the likely causes of recurrent attacks of cystitis (frequency of micturition and dysuria) in a woman following coitus? Dyspareunia, due apparently to vaginismus, has resulted in coitus being infrequent. Full investigation of the urinary tract has proved negative, but on one occasion after discharge from hospital a profuse growth of Bact. coli was obtained from the urine. The condition dates from after the birth of the patient's first child.

A.- - Since the investigations of the urinary tract gave negative results the diagnosis of cystitis must be put in doubt. The occasional finding of Bact. coli in the urine is of little significance unless pus is present as well. Attention might next be directed to the urethra itself and to that part of the vaginal wall immediately around the external meatus. Is there any sign of chronic urethritis with a nidus of infection in Skene's tubules? A more likely finding, however, is a periurethritis which is part of a chronic trichomonal or monilial vaginitis. This can cause symptoms such as those described, and without producing much discharge and pruritus. Moreover, such a condition is not only made worse by coitus but might itself be the cause of the dyspareunia. Careful and repeated examinations of vaginal swabs may be necessary to confirm this diagnosis.

Other possible explanations of the symptoms which come to mind are : (1) Bruising of the urethra during coitus arising as the result of vaginismus, which makes penetration difficult and thrusts the male organ forwards on to the urethra. (2) A urethral reaction to chemicals used as a contraceptive-even to a rubber condom. (3) A defence mechanism in order to avoid coitus for some underlying reason such as fear of pregnancy.

Treatment depends on finding the cause of the trouble.

Corrections.-In the article on "Toxoplasmosis in Relation to Mental Deficiency" (March 28, p. 702) reference was made to the incidence of positive reactions to the Schick test rising with increasing age. The authors of the article write to say that the reference should have been to negative reactions, since in the case of diphtheria, unlike tuberculosis and toxoplasmosis, previous contact with infection results in a negative skin reaction.

In the report of the Extraordinary General Meeting (Supplement, May 9, p. 206) “Mr. F. S. Gould (Birmingham)" should have read "Dr. F. E. Gould (Birmingham)." The error is regretted.

"Any Questions ?" Book : Second Series.-This is now available, price 7s. 6d. (postage 6d. extra), from the Publishing Manager, B.M.A. House, Tavistock Square, London, W.C.1. All communications with regard to editorial business should be addressed
to THE EDITOR, BRITISH MEDICAL JOURNAL, B.M.A. HoUSE, TAVISTOCR
SQUARE, LONDON, W.C.1. TELEPHONE E EUSTON 4499. TELEGRAMS:
Aitiology, Westcent, London. ORIGINAL ARTICLES AND LETTERS
forwarded for publication are understood to be offered to the British
Medical Journal alone unless the contrary be stated.
Authors desiring REPRINTS should communicate with the Publishing
Manager, B.M.A. House, Tavistock Square, W.C.1, on receipt of proofs.
Authors overseas should indicate on MSS. if reprints are required, as
proofs are not sent abroad.
ADVERTISEMENTS should be addressed to the Advertisement Manager,
B.M.A. House, Tavistock Square, London, W.C.1 (hours a.m. to
5 p.m.). TELEPHONE: EUSTON 4499. TELEGRAM: Britmedads,
Westcent. London.
MEMBERS' SUBSCRIPTIONS should be sent to the SECRETARY of MEMBERS' SUBSCRIPTIONS ShUSTON 4499. TELEGRAMS: Medisecra. the Association.

B.M.A. Scotrish OFFICE: 7, Drumsheugh Gardens, Edinburgh. 